munications aura lieu non pas dans des réunions des Sections, mais dans des groupes de réunions de Sections.

En dehors de ces groupes de réunions, les Sections disposeront du temps nécessaire pour lire les communications qui ne sont pas en rapport avec le thème de la Conférence.

\title{
Section notices
}

\section{Utilization Section}

With the aim to compile a review of analysing methods for potatoes and potato products, a working group of the Utilization Section will meet at Göttingen (Germany) in September 1974.

Some thirty members of the Association have been requested to collaborate in the realisation of the project.

Those people, who are also active in this field and do suppose to be able to give a useful contribution to this target, are invited to write to the section's secretary.

Eine Arbeitsgruppe der Sektion Utilization wird im September 1974 in Göttingen (Deutschland) tagen mit dem Ziel, eine Uebersicht der Analysenmethoden für Kartoffeln und Kartoffelprodukte zusamenzustellen.

Es wurden etwa 30 Mitglieder der Gesellschaft um Mitarbeit bei der Realisierung des Projektes angefragt.

Personen, die auf diesem Gebiet aktiv tätig sind und glauben dazu einen nützlichen Beitrag leisten zu können, sind eingeladen, dem Sektionssekretär zu schreiben.

Un groupe de travail de la Section 'Utilisation' se réunira à Göttingen (Allemagne) en septembre 1974 dans le but de composer une revue sur les méthodes d'analyse des pommes de terre et des produits de pommes de terre. Trente membres environ ont été sollicités pour collaborer à la réalisation de ce projet.

Toute personne de l'Association qui exerce une activité dans ce domaine et pense pouvoir apporter une contribution utile à la réalisation de cette tâche, est invitée à écrire au secrétaire de la section.
A. J. D. Howells, secretary, c/o Potato Marketing Board, 50 Hans Crescent, Knightbridge London, SW IX ONB, England 